a comparison of measles virus and poliovirus type 2 serum/C.S.F. ratios in these three cases of subacute sclerosing panencephalitis that measles antibody may be produced or released within the central nervous system. The poliovirus type 2 neutralizing antibody, which acted as an indicator of an intact blood-brain barrier, would be contained in the IgG and IgA fractions. Measles IgM and IgG were present in the C.S.F. of these three patients whereas neither was detected in the C.S.F. of five "normal" patients. The presence of any measles IgM in the C.S.F. is abnormal, since IgM has not been detected in normal C.S.F. (Cohen and Bannister, 1967; Merrill, Hartley, and Claman, 1967). The measles IgG serum/C.S.F. ratio was lower than the poliovirus type 2 serum/C.S.F. ratio in the three patients with subacute sclerosing panencephalitis. These results suggested that both measles IgM and IgG may be produced within the central nervous system. It is unlikely that much antibody was derived from cells in the C.S.F., since the cell count in the three cases was within normal limits.

This work was supported by a grant from the National Fund for Research into Crippling Diseases. We wish to thank the general practitioners for access to patients under their care, Professor K. B. Fraser and Dr. T. A. McNeill for helpful discussions, and Miss Ann J. Fulton for technical assistance.

\section{References}

Baublis, J. V., and Brown, G. C. (1968). Proceedings of the Society for Experimental Biology and Medicine, 128, 206.

Baublis, J. V., and Payne, F. E. (1968). Proceedings of the Society for Experimental Biology and Medicine, 129, 593.

Bouteille, M., Fontaine, C., Vedrenne, Cl., and Delarue, J. (1965). Revue Neurologique, 113, 454

Brown, G. C., Baublis, J. V., and O'Leary, T. (1970). Fournal of Immunology, $104,86$.

Cohen, S., and Bannister, R. (1967). Lancet, 1, 366.

Connolly, J. H. (1968). Neurology (Minneapolis), 18, Part 2, p. 87.

Connolly, J. H., Allen, I. V., Hurwitz, L. J., and Millar, J. H. D. (1967). Lancet, 1, 542.

Connolly, J. H., Allen, I. V., Hurwitz, L. J., and Millar, J. H. D. (1968). Quarterly fournal of Medicine, 37, 625 .

Dawson, J. R. (1933). American fournal of Pathology, 9, 7.
Freeman, J. M., Magoffin, R. L., Lennette, E. H., and Herndon, R. M. (1967). Lancet, 2, 129 .

Haire, M., and Hadden, D. S. M. (1970). British Medical fournal, 3, 130. Horta-Barbosa, L., Fuccillo, D. A., Sever, J. L., and Zeman, W. (1969). Nature, 221, 974 .

Merrill, D., Hartley, T. F., and Claman, H. N. (1967). Fournal of Laboratory and Clinical Medicine, 69, 151.

Schluederberg, A. (1965). Nature, 205, 1232.

Sever, J. L., and Zeman, W. (editors) (1968). Conference on Measles Virus and Subacute Sclerosing Panencephalitis. Neurology (Minneapolis), 18, Part 2.

Svehag, S.-E., and Mandel, B. (1964). Journal of Experimental Medicine, $119,21$.

Uhr, J. W., and Finkelstein, M. S. (1963). Journal of Experimental Medicine, 117,457 .

\title{
Intrinsic-factor Antibody and Absorption of Vitamin B12 in Pernicious Anaemia
}

\author{
M. S. ROSE, I. CHANARIN
}

British Medical fournal, 1971, 1, 25-26

\section{Summary}

The mean urinary excretion in a vitamin- $B_{12}$ absorption (Schilling) test in control subjects was $19.2 \%$ and in pernicious anaemia when given with additional intrinsic factor was as follows: no intrinsic-factor antibodies demonstrable $19.3 \%$, antibodies in serum only $14.4 \%$, antibodies in gastric juice only $11.1 \%$, and antibodies in both serum and gastric juice $8.4 \%$. It is concluded that intrinsic-factor antibody exerts an adverse effect on vitamin- $B_{12}$ absorption in most patients with pernicious anaemia.

\section{Introduction}

The antibody to gastric intrinsic factor present in serum in just over half the patients with pernicious anaemia prevents the binding of vitamin $B_{12}$ to intrinsic factor. When serum containing such an antibody is given orally with vitamin $B_{12}$ it interferes with the absorption of the vitamin mediated by intrinsic factor (Schwartz, 1960). Nevertheless, vitamin- $B_{12}$ absorption (with added intrinsic factor) was found to be essentially the same in those patients with pernicious anaemia who had a demonstrable serum intrinsic-factor antibody and those without (Ardeman and Chanarin, 1965; Yates and Cooper, 1967).

A few cases have been recorded where free antibody to int-

St. Mary's Hospital, London W.2

M. S. ROSE, M.B., B.S., M.R.C. Appointee, Experimental Haematology Unit (Present address: Guy's Hospital, London S.E.1)

I. CHANARIN, M.D., M.R.C.PATH., Consultant Haematologist rinsic factor was present in the gastric secretion associated with impaired absorption of vitamin $\mathbf{B}_{12}$ when given with added intrinsic factor (Schade, Feick, Muckerheide, and Schilling, 1966; Herbert, Carmel, and Li, 1967). Antibody to intrinsic factor was present in the gastric juice in 29 out of 53 $(55 \%)$ pernicious anaemia patients studied by Rose (1970). In $11(21 \%)$ the gastric-juice antibody was found only after it had been dissociated from intrinsic factor. The gastric-juice antibody often occurred in the absence of a demonstrable serum antibody, and of 27 patients without intrinsic-factor antibody in serum, such an antibody was present in gastric juice in 15. The purpose of this report is to describe further observations on these patients wherein the relationship between vitamin- $\mathrm{B}_{12}$ absorption and the presence of intrinsicfactor antibody in serum or gastric juice was studied.

\section{Patients and Methods}

There were 29 patients with pernicious anaemia who were studied at St. Mary's Hospital, London. All had a megaloblastic anaemia due to vitamin-B $B_{12}$ deficiency, histamine-fast or pentagastrin-fast achlorhydria, and impaired absorption of vitamin $\mathbf{B}_{12}$ which was improved to a greater or less extent by additional intrinsic factor. The results in 35 patients with normal gastrointestinal function who were tested over the same period served as controls for vitamin- $B_{12}$ absorption.

Detection of intrinsic-factor antibody in serum was by the method of Ardeman and Chanarin (1963) and in gastric juice by the method of Rose and Chanarin (1969).

Vitamin- $B_{12}$ Absorption Tests.-Vitamin $\mathrm{B}_{12} 1 \mu \mathrm{g}$ labelled with ${ }^{57} \mathrm{Co}$ was mixed with a solution of $20 \mathrm{mg}$ of dried hog intrinsic factor (Lederle WES 818) and given to the fasting patient. This was followed immediately by an injection of 
$1,000 \mu \mathrm{g}$ of cyanocobalamin and a 24-hour collection of urine. A plasma sample was taken 10 to 12 hours after the oral dose of vitamin $\mathrm{B}_{12}$. Radioactivity was measured in both an aliquot of urine and the plasma sample. If the results by these two methods did not agree, suggesting incomplete urine collection, the result of the urine test was rejected and the test repeated.

\section{Results}

The results are shown in the Table. There was no significant difference in the urinary excretion of vitamin $B_{12}$ between the

Results of Vitamin- $B_{12}$ Absorption Tests (Urinary Excretion; Schilling Test). Percentage of Oral $1-\mu \mathrm{g}$ Dose of ${ }^{57} \mathrm{Co}-$ Vitamin $B_{12}$ in Urine

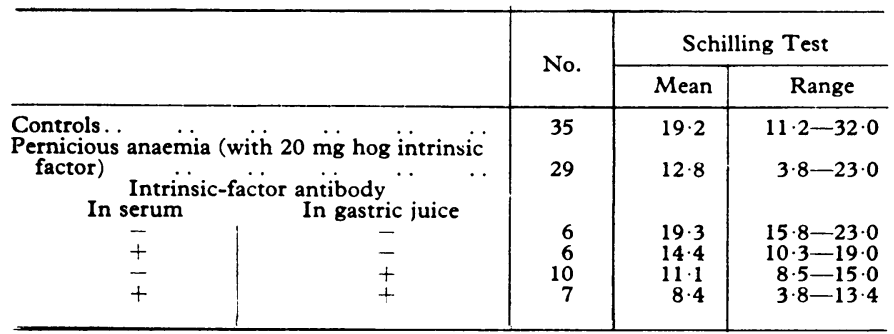

control subjects, the pernicious anaemia group without demanstrable antibody, and the pernicious anaemia group with only serum antibody. On the other hand, the group with antibody in gastric juice excreted (and hence absorbed) significantly less vitamin $B_{12}$ than did those pernicious anaemia patients without antibody $(P=0.01)$, and this was even more so when the group with antibody in both serum and gastric juice was considered.

\section{Discussion}

Though it has been accepted that under special circumstances antibody to intrinsic factor will interfere with vitamin- $B_{12}$ absorption, the data presented here indicate that in pernicious anaemia this is the rule rather than the exception. The most pronounced effect was found in the "best antibody formers"that is, those who had antibody in both serum and gastric juice. The data also indicate that the presence of antibody is an important factor in producing the severe degree of malabsorption of vitamin $B_{12}$ that leads to severe vitamin- $B_{12}$ deficiency. Thus the appearance of an intrinsic-factor antibody is able to convert a moderate degree of vitamin- $B_{12}$ malabsorption that does not necessarily lead to vitamin- $\mathbf{B}_{12}$ deficiency (as in many cases of atrophic gastritis) to the relatively severe malabsorption found in pernicious anaemia.

On the other hand, the data confirm previous observations. that serum antibody alone is less significant and where the antibody is confined to the serum compartment may have no effect at all on vitamin- $B_{12}$ absorption (Rose, Chanarin, Doniach, Brostoff, and Ardeman, 1970).

\section{References}

Ardeman, S., and Chanarin, I. (1963). Lancet, 2, 1350.

Ardeman, S., and Chanarin, I. (1965). Gut, 6, 436

Herbert, V., Carmel, R., and Li, J. G. (1967). New England fournal of Medicine, 276, 61 .

Rose, M. S. and Chanarin, I. (1969). British Medical fournal, 1, 468.

Rose, M. S. (1970). Ph.D. Thesis, University of London. Rose, M. S. (1970). Ph.D. Thesis, University of London.

Schade, S. G., Feick, P., Muckerheide, M., and Schilling, R. F. (1966) New England fournal of Medicine, 275, 528

Schwartz, M. (1960). Lancet, 2, 1263 .

Yates, T., and Cooper, B. A. (1967). Canadian Medical Association fournal. $97,950$.

\title{
Factors Predisposing to Recurrent Haemorrhage after Acute Gastrointestinal Bleeding*
}

\author{
T. C. NORTHFIELD
}

British Medical Fournal, 1971, 1, 26-28

\section{Summary}

A retrospective survey of 472 consecutive hospital admissions for acute upper gastrointestinal bleeding showed that patients with a large initial bleed are more likely to bleed again than those with a small initial bleed. The incidence of recurrent haemorrhage is also related to the interval since the last bleeding episode, so that patients showing no clinical evidence of haemorrhage for 48 hours are unlikely to bleed again in the near future. Patients admitted after a haematemesis have a higher incidence of recurrent haemorrhage than those admitted after melaena only. Aetiology has been confirmed as an additional important factor, the incidence being highest in those with oesophageal varices or a chronic gastric ulcer. Contrary to widespread belief, age does not appear to affect the incidence of recurrent haemorrhage, nor do other constitutional factors such as sex or the ABO blood group.

- This paper is based on part of an M.D. thesis submitted to Cambridge University.

Central Middlesex Hospital, Park Royal, London N.W.10

T. C. NORTHFIELD, M.D., M.R.C.P., formerly Medical Registrar, Department of Gastroenterology (Present address: Guy's Hospital, London S.E.1)

\section{Introduction}

Recurrent haemorrhage after admission to hospital results in a twelvefold increase in medical mortality rate (Avery Jones, 1956) and is therefore generally regarded as the main indica- N tion for emergency surgery. Unfortunately, a policy of selective emergency surgery in these patients has failed to reduce the overall mortality rate significantly (Avery Jones, 1956; Schiller et al., 1970). An improvement in mortality rate seems more likely to result from a policy of operating on patients before, rather than after, they rebleed, so that a method of recognizing patients at special risk of recurrent haemorrhage might have important therapeutic implications. Apart from the observation that patients with a chronic gastric ulcer are at an increased risk (Avery Jones, 1956), very little is known about factors predisposing to recurrent haemorrhage.

Methods

Careful records are kept in the gastroenterology department of all patients admitted to the Central Middlesex Hospital with acute gastrointestinal bleeding. Almost all these patients are admitted to one of the two gastroenterology wards. This system offers considerable advantages for retrospective analysis, 